Bjarnegård, Elin. 2013. Gender, Informal Institutions and Political Recruitment. Basingstoke: Palgrave Macmillan.

Bjarnegård, Elin, Erik Melander, Gabrielle Bardall, Karen Brounéus, Erika Forsberg, Karin Johansson, Angela Muvumba Sellström, and Louise Olsson. 2015. "Gender, Peace and Armed Conflict." In SIPRI Yearbook 2015. Oxford: Oxford University Press, 101-9.

Daxecker, Ursula E. 2012. "The Cost of Exposing Cheating: International Election Monitoring, Fraud, and Post-election Violence in Africa." Journal of Peace Research 49 (4): $503-16$.

Fischer, Jeff. 2002. Electoral Conflict and Violence. Washington, DC: International Foundation for Electoral Systems.

Hyde, Susan, and Nikolay Marinov. 2012 "Which Elections Can Be Lost?" Political Analysis 20 (2): 191-201.

Höglund, Kristine. 2009. "Electoral Violence in Conflict-Ridden Societies." Terrorism and Political Violence 21 (3): 412-27.

Krook, Mona Lena. 2017. "Violence against Women in Politics." Journal of Democracy 28 (1): 74-88.

Krook, Mona Lena, and Juliana Restrepo Sanín. 2016a. "Gender and Political Violence in Latin America.” Politica y Gobierno 23 (1): 125-57.

- 2016b. "Violence against Women in Politics: A Defense of the Concept." Politicay Gobierno 23 (2): 459-90.

Norris, Pippa. 2013. “The New Research Agenda Studying Electoral Integrity.” Electoral Studies 32 (4): $563-75$.

Piscopo, Jennifer. 2016. "State Capacity, Criminal Justice, and Political Rights: Rethinking Violence against Women in Politics." Politica y Gobierno 23 (2): 437-58.

United Nations Office on Drugs and Crime (UNODC). 2013. "Global Study on Homicide 2013." https://www.unodc.org/documents/data-and-analysis/statistics/GSH2013/2014_ GLOBAL_HOMICIDE_BOOK_web.pdf (accessed August 20, 2018).

World Health Organization (WHO). 2013. "Global and Regional Estimates of Violence against Women." http://www.who.int/reproductivehealth/publications/violence/97892 41564625/en/ (accessed August 20, 2018).

\title{
Turning the Tide on Violence against Women in Politics: How Are We Measuring Up?
}

\section{Julie Ballington, UN Women}

doi:10.1017/S1743923X18000636

Violence against women in politics (VAWP) is a human rights violation, as it prevents the realization of political rights. Violence against women in political and public life can be understood as "any act or threat of

This article has benefited from contributions by Gabriella Borovsky. 
gender-based violence, resulting in physical, sexual, psychological harm or suffering to women, that prevents them from exercising and realizing their political rights, whether in public or private spaces, including the right to vote and hold public office, to vote in secret and to freely campaign, to associate and assemble, and to enjoy freedom of opinion and expression" (UN Women/UNDP 2017, 20).

Although awareness of the gravity and increasing levels of VAWP is growing, the issue is a relatively new area of investigation, with no global statistics or measurements available on prevalence or incidence, a lack of commonly agreed definitions and indicators, a reliance on anecdotal evidence, and underreporting because of the stigma attached to genderbased violence in many societies. The absence of commonly agreed definitions and methodologies for measuring VAWP is a barrier to the advancement of research, monitoring, and policy and programming responses in this field. Are agreed indicators and methodologies for measuring VAWP necessary? How can consistency across different measurement approaches be ensured? This essay examines the extent to which VAWP is measured, identifying gaps in current violence against women (VAW) measurements and considering new opportunities for measuring and monitoring VAWP.

\section{THE CASE FOR MEASURING VAWP}

There is an emerging consensus among practitioners, researchers, and stakeholders that efforts to eliminate or prevent VAWP must include adequate measurement and monitoring. Statistics on violence against women in general show that it is pervasive, ranging globally between $30 \%$ and $70 \%$ of women having experienced physical and/or sexual violence by a partner or sexual violence by a nonpartner at some point in their lifetime (UN Women 2012; WHO 2013). Unfortunately, VAW measurements developed over the past decade have neglected to include the political sphere, possibly because the scope of VAWP was less than it is today, or because there was less public acknowledgment of this problem. There are also only a handful of internationally agreed indicators for measuring women's political participation, none of which include VAWP, constituting a major gap in this area (UN 2013).

The UN Secretary General's report on women and political participation (2013) noted that "the comprehensive investigation of allegations of violence, assault, or harassment of women elected officials 
and candidates for political office is an important step in creating an environment conducive to women's political participation." Since recognition of VAWP is relatively new, few states report on it. The report recommended that solutions start with fact-based assessments, such as vulnerability mapping or violence monitoring, both to document the scope of the issue and to identify appropriate and effective mitigation measures. In this essay, I argue there are three avenues through which the VAWP evidence base can be established: adapting (1) standard VAW measurements, which measure prevalence, including the Sustainable Development Goals; (2) broader political and electoral violence monitoring, which mostly measures incidence; and (3) country-level quantitative and qualitative studies, including testimonials, which provide more concrete and detailed insights into cases of VAWP.

\section{STANDARD VIOLENCE AGAINST WOMEN MEASUREMENTS ${ }^{1}$}

Reliable statistics are recognized as necessary to help eliminate all forms of $\mathrm{VAW},{ }^{2}$ and the need to improve the collection and use of VAW data is high on the international agenda. In 2011, a set of nine core VAW indicators (such as rates of physical, sexual, and psychological violence experienced by women, broken down by age group) were identified and approved by the UN Statistical Commission, followed in 2014 by guidelines for producing these statistics by the UN Statistics Division (UN 2014). These guidelines were developed in consultation with various stakeholders to produce common indicators for use by national statistical offices worldwide.

The development of core VAW indicators and guidelines for collection is important for ensuring consistency of measurement across countries. ${ }^{3}$ However, standard indicators to measure the prevalence of VAW - in the family, the community, and the state - have overlooked the political sphere. Filling this gap might simply entail adding questions or response options recognizing that the "perpetrator" or "place of occurrence" might be in politics. Though this approach might be limited by the specificity of the VAW indicators, it would enable minimum data on VAWP to be collected systematically and consistently across countries via

1. This section has benefited immensely from ideas provided by Juncal Plazaola Castaño.

2. See the Declaration on the Elimination of Violence against Women (1993) and General Assembly Resolution 48/104.

3. More than 100 countries have conducted at least one prevalence survey, and more than 40 countries have conducted at least two surveys (UN 2015). 
standard, agreed indicators. Collecting data on VAWP, moreover, may be less challenging than collecting data on intimate partner violence (where many hold the strong view that it is a private issue) or nonpartner sexual violence (which is often associated with stigma).

National surveys, multicountry studies, and administrative data on VAW collected through public and private services that come into contact with women survivors of violence are also potential entry points for measuring the prevalence of VAWP. National surveys or multicountry studies can assess the magnitude of the problem and raise awareness among stakeholders about its existence. ${ }^{4}$ Administrative data are not comprehensive enough to measure the magnitude and patterns of VAW, as many women do not report violence and those who do tend to be only the most serious cases. However, data collected from health centers, police stations and courts, housing and social welfare services and shelters, and other support services are potential sources for determining the number of cases, the response provided, and/or the referral mechanism put in place, aiding countries in estimating their needs and costs (UN 2014).

The Sustainable Development Goals (SDGs) offer additional opportunities to measure VAWP through data collected to monitor progress toward Goal 5, Target 5.2, on eliminating all forms of violence against women and gender in private and public spheres; Goal 11, Target 11.7, on providing universal access to safe and inclusive public spaces; and Goal 16, Target 16.1, on significantly reducing all forms of violence and related death rates. These indicators are aligned with the core VAW indicators, and related SDG monitoring efforts require reliable and comparable prevalence data collected in line with existing globally agreed standards. The subindicators 5.2.2, on sexual violence by a nonpartner, and 11.7.2, on physical and sexual harassment, require data to be disaggregated by place of occurrence. Here, public office may be suggested as one of the places of occurrence of violence to be explored. The scope of controlling behaviors could also potentially be broadened to include controlling behaviors of women in political and public life, including for example, incidents in which women are prevented from voting by a partner or coerced to vote a particular way.

4. Personal interview with Juncal Plazaola Castaño. 


\section{POLITICAL AND ELECTORAL VIOLENCE MONITORING}

Political violence monitoring programs and international and domestic election observation have the potential to provide quantitative information on VAWP. By integrating a gender dimension in their reporting, or developing VAWP-specific indicators, international election observation missions, domestic observations, and early warning systems can contribute to understanding the incidence of VAWP at specific points in time. There are positive innovations in this regard. For example, the National Democratic Institute's "Votes without Violence" toolkit, which has been piloted in several countries, provides citizen observer groups (particularly long-term observers) with gender-sensitive assessment tools and training on how to identify and record incidents of violence against women in elections (NDI 2016). Similarly, the International Foundation for Electoral Systems' "Violence against Women in Elections Framework" has been developed as a monitoring tool to track VAW throughout all phases of the electoral cycle (IFES 2017). These tools could contribute to filling the data gap. However, it may be useful to consider common indicators or approaches in collection methodologies and questions used in report forms to ensure consistency and comparability of data.

\section{VAWP CASE STUDIES AND TESTIMONIALS}

An additional promising source of data involves national case studies and testimonials, capturing both qualitative and quantitative information on VAWP. Several pilot projects have sought to collect data through multipartner initiatives, including in partnership with civil society organizations. These include academic analyses and research commissioned by development organizations using a variety of data points and measurement. One example of the rich information provided by such case studies is a UN Women initiative together with the Tanzania Women's Cross-Party Platform to collect data on violence against women in the 2015 elections in Tanzania. This report used both quantitative and qualitative research methods, including interviews, to confirm the occurrence of psychological, physical, and sexual violence during the elections.

In another example, the Inter-Parliamentary Union interviewed 55 parliamentarians from 39 countries about their perceptions and experiences of harassment, intimidation, and violence, as well as possible motivations for the violence (IPU 2016). The analysis revealed troubling 
levels of violence against women parliamentarians, with $81.8 \%$ of survey participants having experienced some form of psychological violence while serving their terms, mainly through social media. Complementary initiatives include ParlAmericas' video project, "Mapping Gender-Based Political Harassment: Parliamentarians Speak Out," an online space featuring testimonies of women parliamentarians from across the Americas and the Caribbean on the topic of VAWP (ParlAmericas 2017), and the National Democratic Institute's Incident Report Form, collecting testimonies of violence in order to highlight its global nature (NDI 2017).

\section{CONCLUSION}

The various sources of data outlined here may collectively contribute to filling the VAWP data gap. There are lessons learned from the development of the VAW measurements and indicators, which could help inform the development of standardized VAWP measurements, namely, (1) a strong call for data collection and research established through international resolutions agreed by states, urging states to report progress, and (2) a minimum set of agreed indicators, establishing clear methods and guidelines for data collection, improving comparability of data across countries. While an entirely new approach may not be necessary, an integrated one that aims to measure VAWP through agreed standards and indicators is a compelling way forward. In addition, data collected during electoral observation missions can provide quantitative information on incidences at particular moments in time, and national case studies on VAWP can provide qualitative information on specific incidents. Consistent standards will significantly improve data collection efforts and measurement of VAWP in the long term.

Julie Ballington is Policy Advisor for Political Participation at UN Women, New York: julie.ballington@unwomen.org

\section{REFERENCES}

International Foundation for Electoral Systems. 2017. "Violence against Women in Elections: A Framework for Assessment, Monitoring, and Response." http://www.ifes. org/publications/violence-against-women-elections (accessed August 20, 2018).

Inter-Parliamentary Union. 2016. "Sexism, Harassment, and Violence against Women." Issue Brief, October. https://www.ipu.org/resources/publications/reports/2016-10/sexismharassment-and-violence-against-women-parliamentarians (accessed August 20, 2018). 
National Democratic Institute (NDI). 2016. "Votes without Violence: A Citizen Observer's Guide to Addressing Violence against Women in Elections." https://www.ndi.org/voteswithout-violence (accessed August 20, 2018).

—_ 2017. "Incident Report Form: Violence against Women in Politics." https://www.ndi. org/incident-report-form-violence-against-women-politics (accessed March 7, 2018).

ParlAmericas. 2017. "Mapping Gender-Based Political Harassment: Parliamentarians Speak Out." http://www.parlamericas.org/en/gender-equality/political-harassment-map. aspx (accessed March 7, 2018).

UN Women. 2012. "Violence against Women Prevalence Data: Surveys by Country." http://www.endvawnow.org/uploads/browser/files/vawprevalence_matrix_june2013.pdf (accessed August 20, 2018).

UN Women/UNDP. 2017. "Preventing Violence against Women in Elections: A Programming Guide.” http://www.unwomen.org/en/digital-library/publications/2017/ 11/preventing-violence-against-women-in-elections (accessed August 20, 2018).

United Nations (UN). 2013. "Measures Taken and Progress Achieved in the Promotion of Women and Political Participation: Report of the Secretary General." Report A/68/ 184, July 24. https://documents-dds-ny.un.org/doc/UNDOC/GEN/N13/406/99/PDF/ N1340699.pdf?OpenElement (accessed August 20, 2018).

— . 2014. "Guidelines for Producing Statistics on Violence against Women." https:// unstats.un.org/unsd/gender/docs/guidelines_statistics_vaw.pdf (accessed August 20, 2018).

— . 2015. “The World's Women 2015." https:/unstats.un.org/unsd/gender/downloads/ worldswomen2015_report.pdf (August 20, 2018).

World Health Organization (WHO). 2013. "Global and Regional Estimates of Violence against Women." http://www.who.int/reproductivehealth/publications/violence/ 9789241564625/en/ (accessed August 20, 2018). 